\author{
巨 東英 (埼玉工業大学), 齋藤 大道, 張 終博 (埼玉工業大学大学院), \\ 市谷 克美 (出光興産株式会社)
}

\title{
Visualization of thermal flow on domain near to quenching products
}

\author{
Dong-Ying JU* , Hiromichi SAITO** , Zhang Zhong Bo** and Katsumi ICHITANI*** \\ * Faculty of Engineering, Saitama Institute of Technology, Japan \\ ** Graduate school of Engineering, Saitama Institute of Technology, Japan \\ ***IDEMITSU KOSAN CO., LTD
}

\begin{abstract}
In the quenching process, heat transfer behavior will is very complex due to boiling, generation of the bubble by the boiling in the quenchant, flaking off of steam film in metal surface. In this research, the behavior of steam film in quenching process was investigated with high-speed video camera by visualization method. The behaviors of the boiling bubbles including generation and movement as well as the breaking during stirring quenching process were clarified. The flow velocity fields around the quenching parts at no stirring and stirring quenching with various flow velocities on nozzle were investigated. In order to identify the heat transfer coefficients by using of the measured cooling curves of surface temperature. Effects of stirring and oil temperature on breaking the steam film were confirmed.
\end{abstract}

Keywords: Quenching, Flow visualization, PIV, Cooling curves.

\section{1. 緒言}

焼入れとは, 機械部品の耐摩耗性および疲労強度を向上 させる熱処理技術である。しかし, 焼入れの際に冷却剤の 沸騰による気泡の発生, 金属表面における蒸気膜の生成・ はく離および熱対流などの現象が発生する. 冷却剂と試験 片の間に蒸気膜ができると、焼入れ性が阻害されてしまう。 これらによって冷却の不均一化を及ぼし, 変形のばらつき などの欠陷が生じる.

本研究では, 油焼入れ実験を行い, 焼入れ部品における 冷却の均一化を図るために冷却剂の靦拌と油温の調節を 行う. そして, それらが焼入れ中に発生する蒸気膜一及ぼ す影響をハイスピードカメラ, PIV 測定, 熱電対を用いて 観察する.これらより, 焼入れ過程における焼入れ油の伝 熱挙動と熱流れの可視化を行う. また, 本実験装置におけ る流れの定量化を行うために, 冷却槽内の各部において流 れの測定を行う。

\section{2. 実験装置と実験方法}

\section{1 実験装置}

Fig. 1 に実験装置の概要と Fig. 2 に冷却槽の寸法と写真 を示す. 試験片を加熱するための電気炉があり, その真下 に泠却槽が設置されている. 冷却槽は透明のアクリル材を 使用しており, 焼入れ中の様子の可視化が行えるようにな っている. 試験片の泠却槽への投入は自動化されているた め, 再現性が高くなっている. 試験片の温度測定には熱電 対を使用し, 最大 3 点での同時測定が可能である. 冷却剂 はモータポンプを使用し循環させることができ, 冷却槽底 面部から最大 $1.5 \mathrm{~m} / \mathrm{s}$ で流入させ靦挥を行うことが出来る。 また, リザーブタンクにてヒータを用い液温の調節が可能 となっている. そして, 流量計と流量調節バルブにより流 量の調節が可能である.

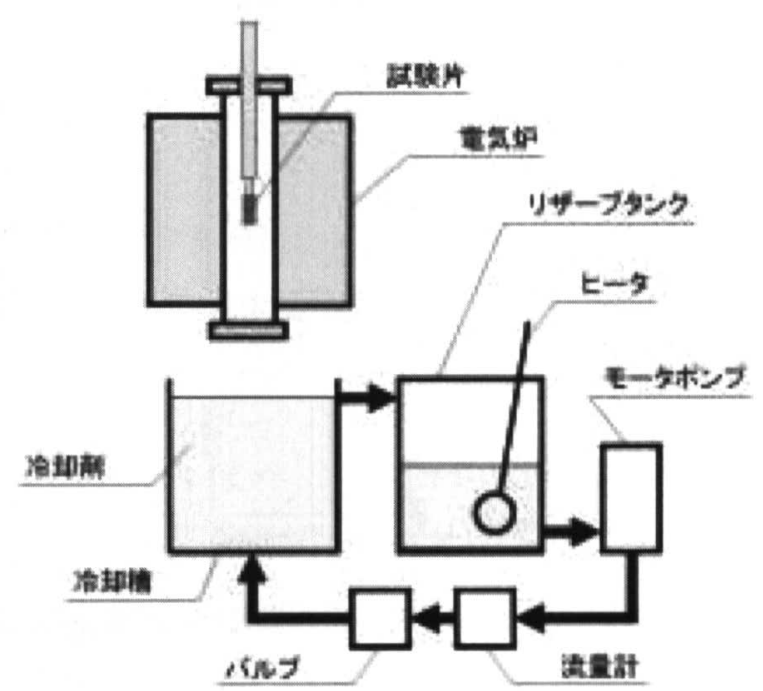

Fig.1 実験装置の概要
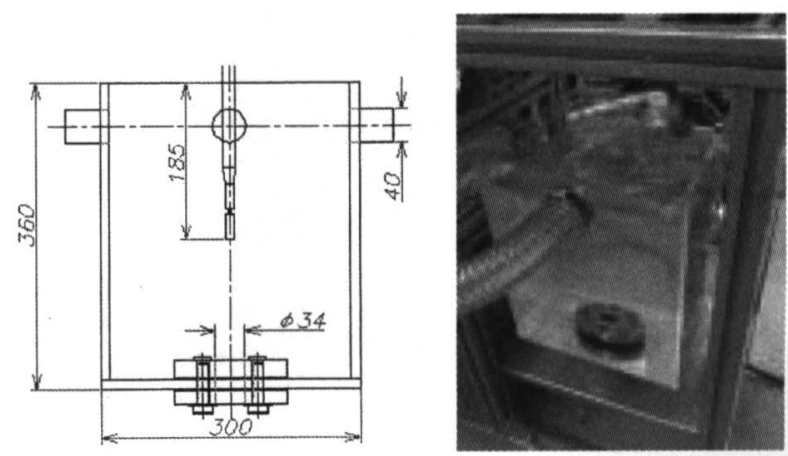

Fig. 2 冷却槽 


\section{2 実験方法}

まず電気炬にて試験片を加熱する. 試験片には Fig. 3 に 示すような $\phi 10 \mathrm{~mm} \times 30 \mathrm{~mm}$ の銀棒を使用し, 加熱温度は $810^{\circ} \mathrm{C}$ とした. 加熱完了後試験片を冷却槽に投入し焼入れ を行う.焼入れを行う際の椧却剂にはダフニーブライトク エンチ油を使用し, 液温は $40^{\circ} \mathrm{C}, 60^{\circ} \mathrm{C}, 80^{\circ} \mathrm{C}$ の 3 種類, 䚑拌状態は $9 \mathrm{~L} / \mathrm{min}, 18 \mathrm{~L} / \mathrm{min}, 27 \mathrm{~L} / \mathrm{min}$ の 3 種類, 試験 片の温度測定時間は 12 秒とし, 測定間隔は $10 \mathrm{~ms}$ に設定 した.

\section{3 可視化方法}

Fig.4 に可視化方法の概要を示す. まずレーザを発生さ せレンズによってレーザをシート状にし, それを泠却槽側 面から当てる.この状態で椧却槽正面よりハイスピードカ メラを用いて焼入れ過程における蒝気膜の観察と泠却剤 の流れの可視化を行う. また, ハイスピードカメラより得 られた画像から PIV 測定を行う。 その際は冷却槽内に発 生している気泡を粒子とみなした. 試験片周りの流れの解 析範囲を Fig.5 に示す.

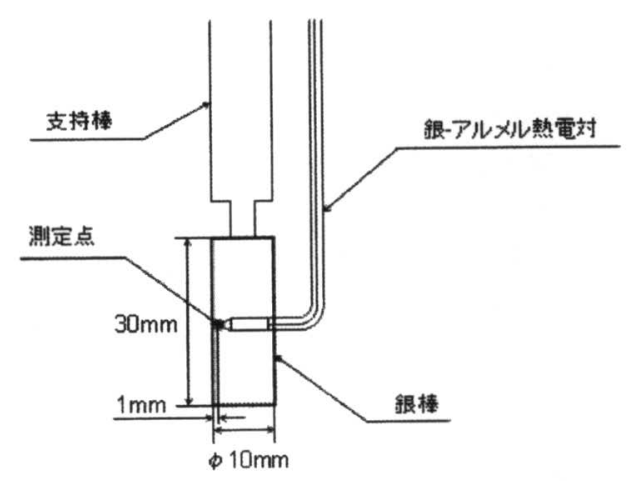

Fig.3 試験片

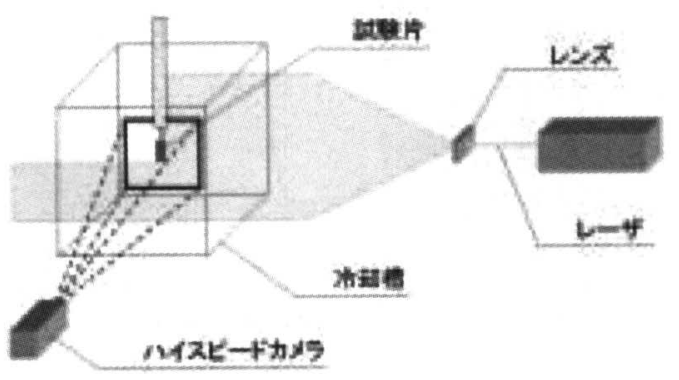

Fig.4 可視化方法の概要

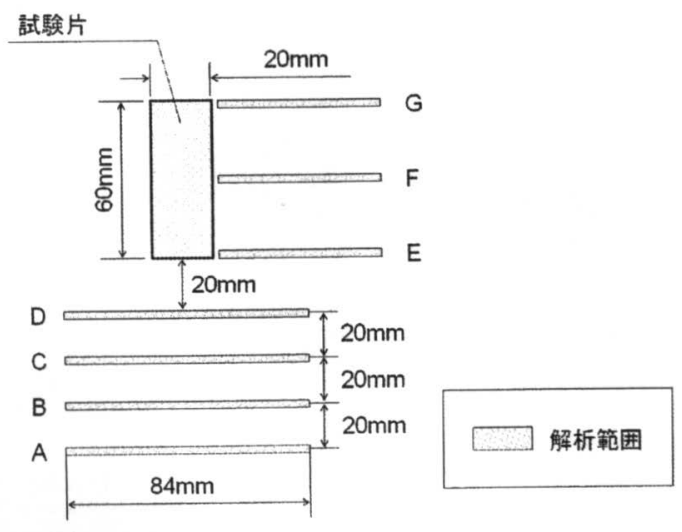

Fig.5 試験片周辺の流れ解析範囲

\section{3. 実験結果及び考察}

\section{1 温度測定結果}

Fig.6に各流量での温度測定結果を示す．グラフには縌 軸に温度, 横軸に時間を取り, 各流量において冷却材の温 度変化による影響を泠却曲線で示す. 結果からは全ての流 量において 2 秒から 3 秒付近において冷却が急速に行わ れていることが分かる.これは試験片を覆っていた蒸気膜 が崩壊したためと考えられる. また, 冷却剂の液温を上げ ることによって冷却が早く行われていることが分かる.こ れは冷却剂の液温を上げることにより試験片との温度差 が少なくなり, 蒸気膜の崩壊過程を早める結果になったと 考えられる。

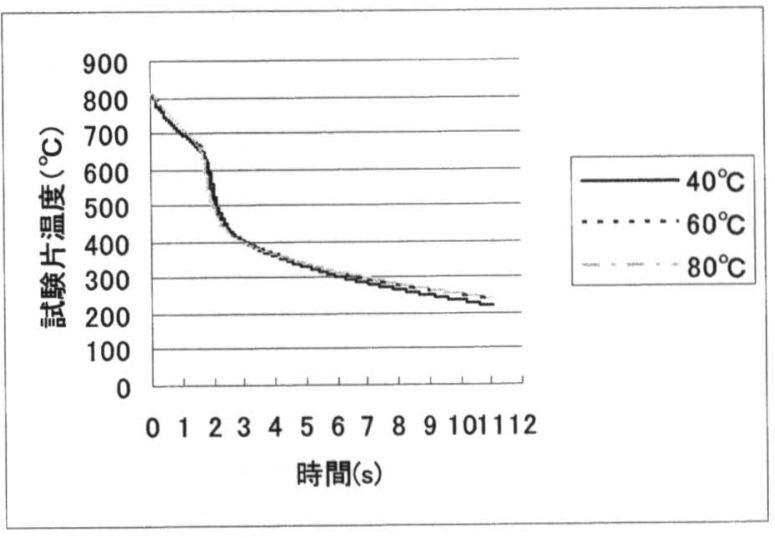

$9 \mathrm{~L} / \mathrm{min}$

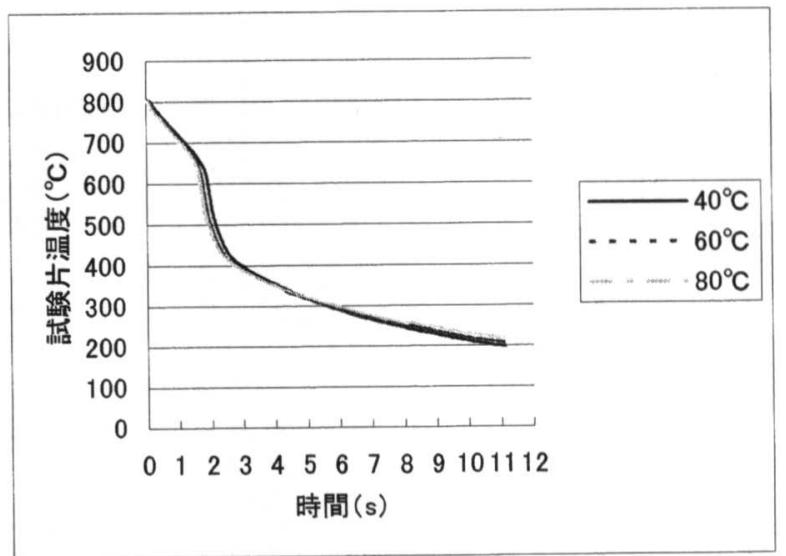

$18 \mathrm{~L} / \mathrm{min}$

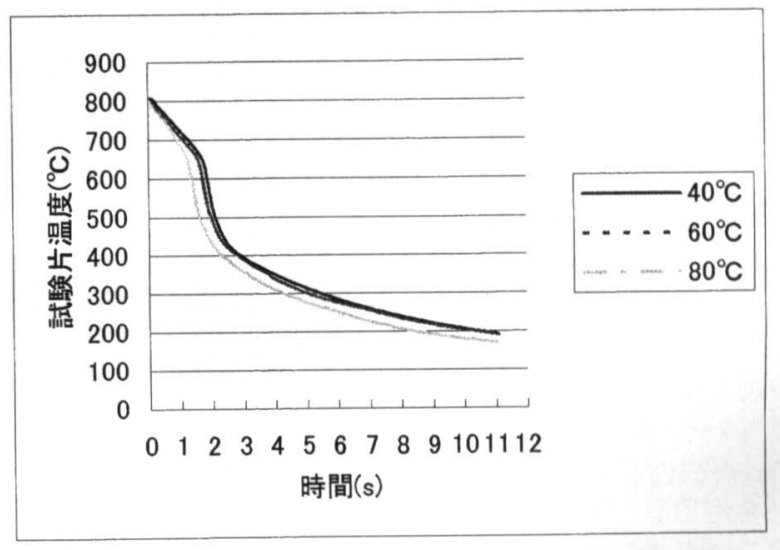

$27 \mathrm{~L} / \mathrm{min}$

Fig.6 各流量での温度測定結果 


\section{2 ハイスピードカメラによる可視化結果}

Fig.7 に焼入れ時の蒸気膜崩壊過程の様子として描拌を 行っていない状態のものを一例として示す. まず試験片全 体が蒸気膜に覆われる状態となる. 次に試験片の下の部分 から蒸気膜の崩壊が始まり $(\mathrm{t}=3.1 \mathrm{~s})$, 徐々に試験片の上 に向かって崩壊の様子が確認できた（ $\mathrm{t}=3.3 \mathrm{~s}, \mathrm{t}=3.5 \mathrm{~s})$. また, その際には小さい気泡同士がくっ付き合い大きい気 泡へと変化していることも確認できた. Fig.8には, 各挸 汼状態と液温状態における蒸気膜の崩壊過程の比較を示 す. グラフからは流速が早くなるほど, また冷却剤の液温 が高くなるほど蒸気膜の付着している時間と崩壊までに かかる時間が少なくなっている傾向が確認できる.
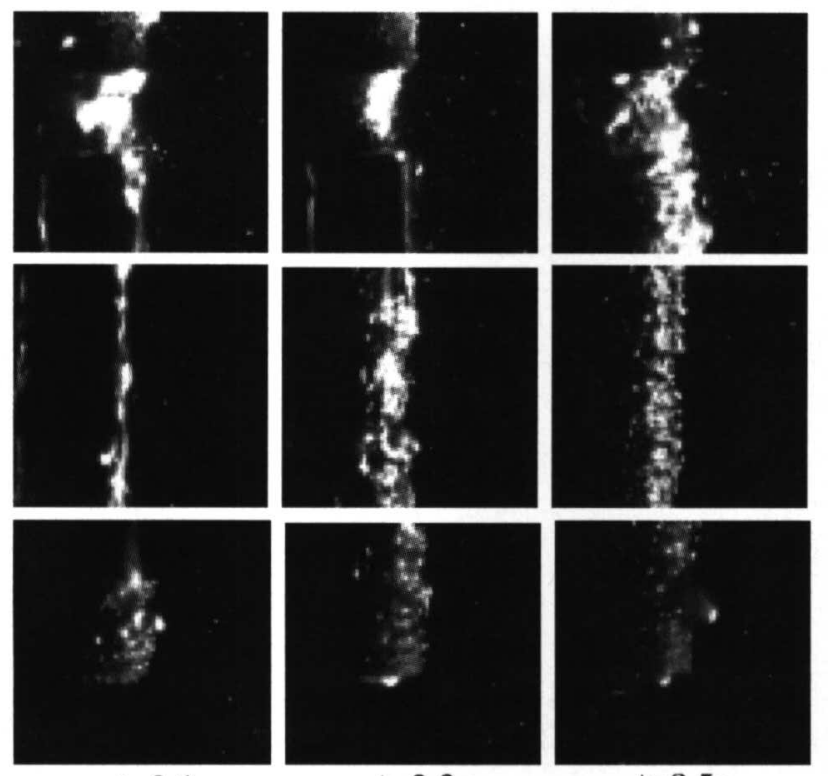

Fig.7 焼入れ時の蒸気膜崩壊過程の様子

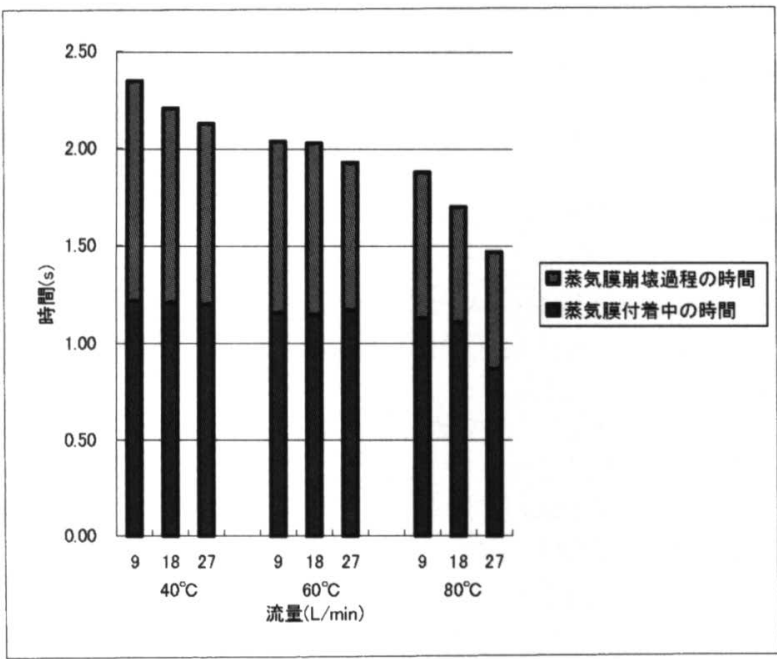

Fig.8 焼入れ時の蒸気膜崩壊過程の様子

\section{3 試験片周辺における流れの測定結果}

Fig. 7 に解析を行った際のベクトル図を示し, Fig.8 に 試験片周りにおける流れの解析結果を示す. まず試験片下 の部分における解析結果（流入口部分, A〜D）について は, 流入口から試験片に近づくにつれ流れが弱まっている ことが確認できる. また, 流れを強くした場合その減少量 も多くなっていることが分かると共に, 流入口の径より流 れの幅が広がっていることが分かる. 流れの減少について は, 冷却剂の粘度に依存している部分が大きいと考えられ
る. 次に試験片横の部分における解析結果 $(\mathrm{E} \sim \mathrm{G})$ につ いては, 全ての流量において最も早い流れが $\mathrm{E}$ (試験片下 部）において確認でき, G（試験片上部）に向かうにつれ 弱まっていることが分かる. また, 試験片の距離から見た 最も早い流れは, E (試験片下部) が最も試験片に近い位 置で確認でき，F，G と上に向かうにつれ試験片からの距 離が開いていることが分かる.このことから, 試験片と試 験片に沿って上に向から流れとの間に渦が発生し境界層 が出来ており, その境界層が上に向からほど広がっている ことが考えられる. また, 実際に試験片近傍において流れ が弱まっていることを確認するために, Fig.9に写真から 気泡の動きを追跡したところ, 解析結果と同じような結果 が得られた.

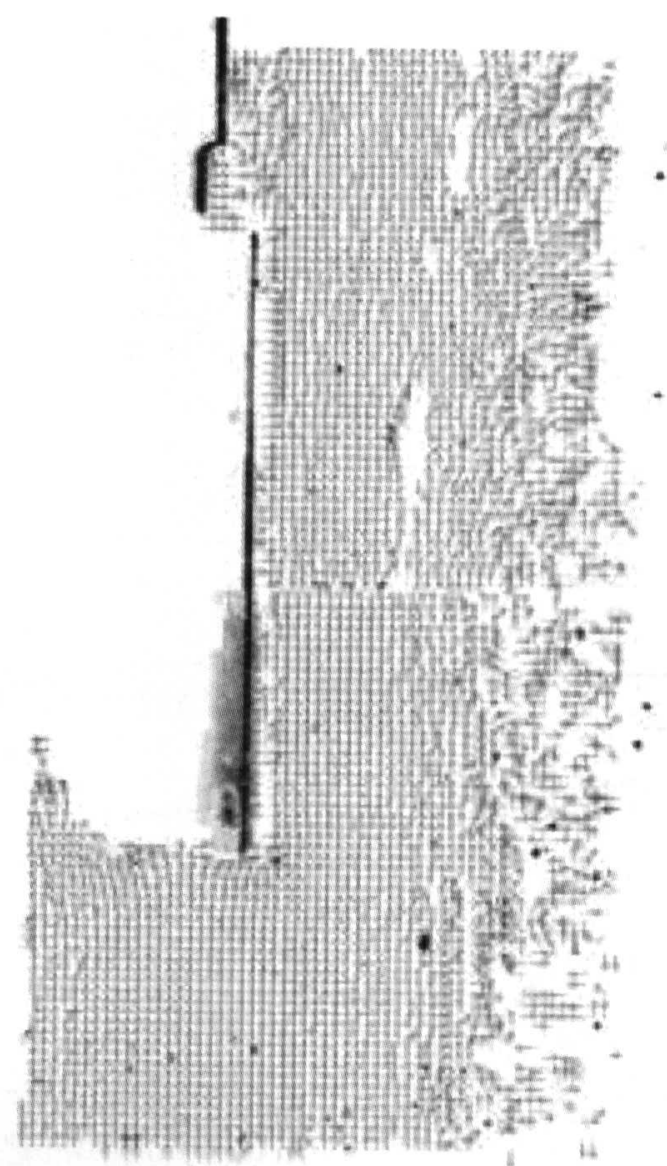

試験片周辺部

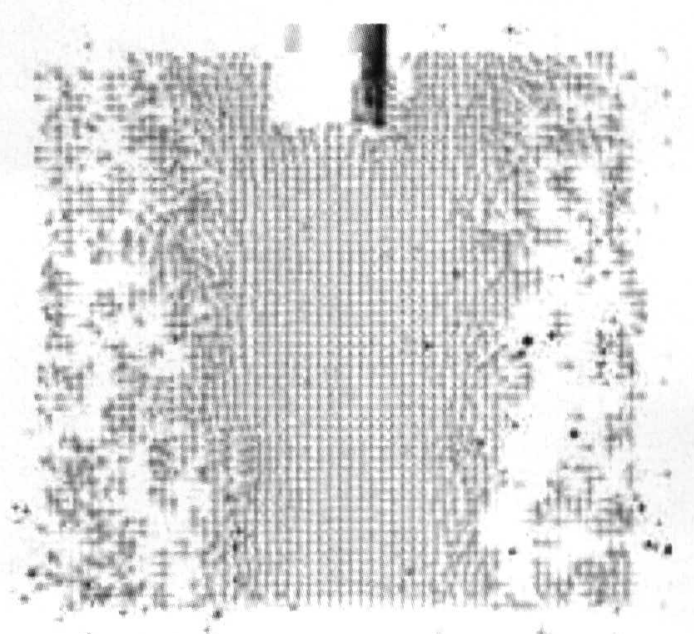

試験片下部

Fig.7 試験片周りにおける流れの様子（液温 $20^{\circ} \mathrm{C}$ ) 

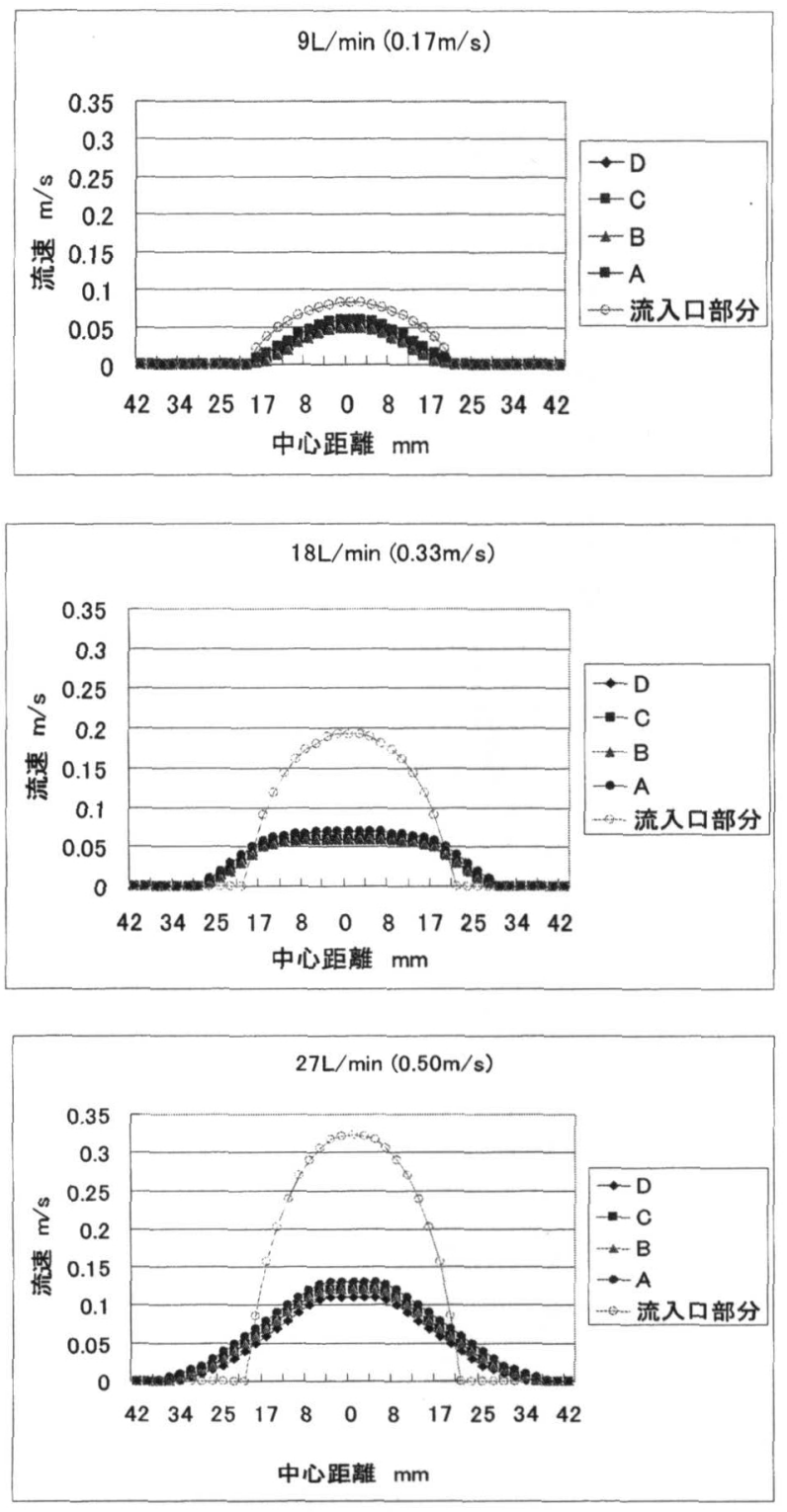
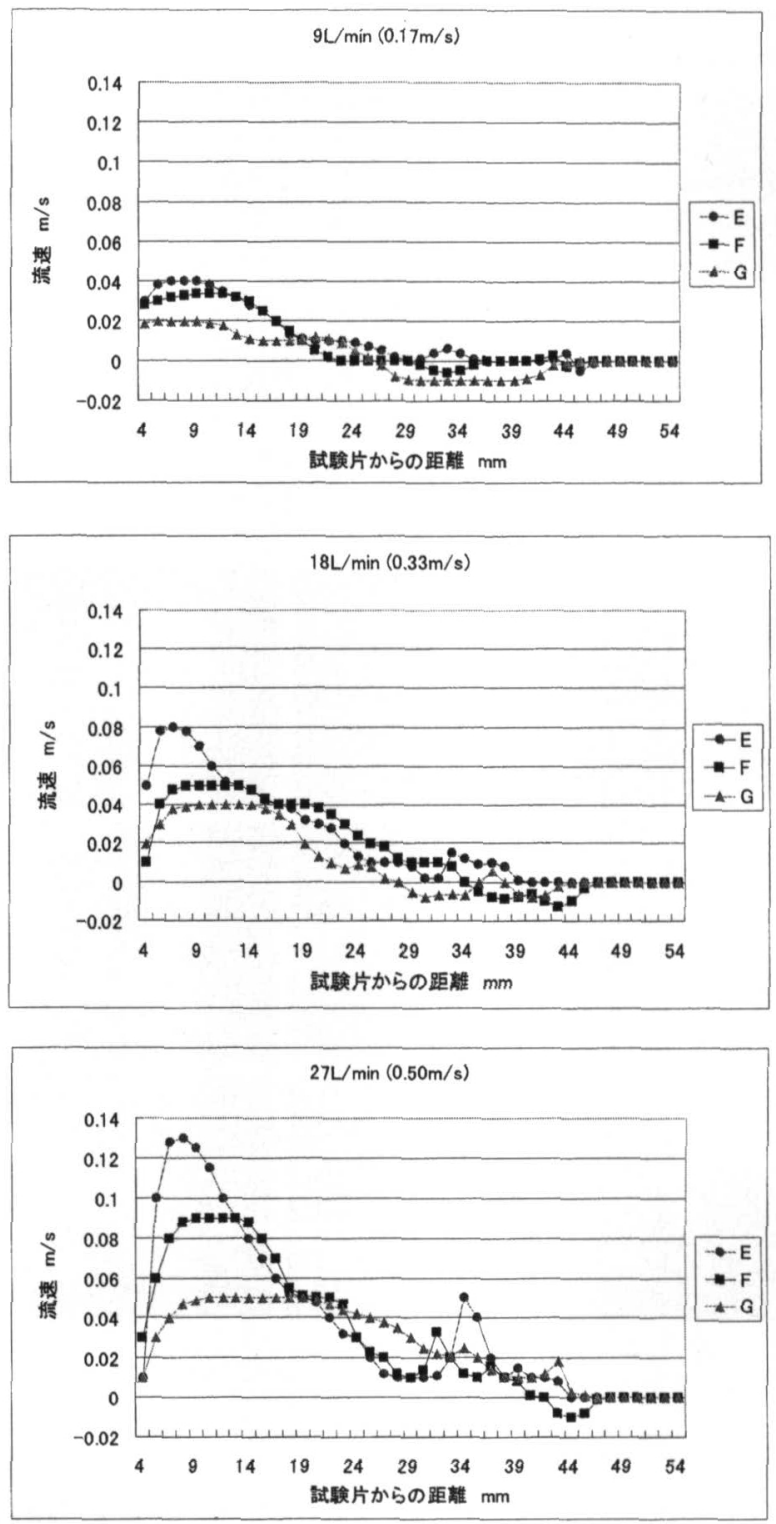

Fig.8 試験片周りにおける流れの解析結果
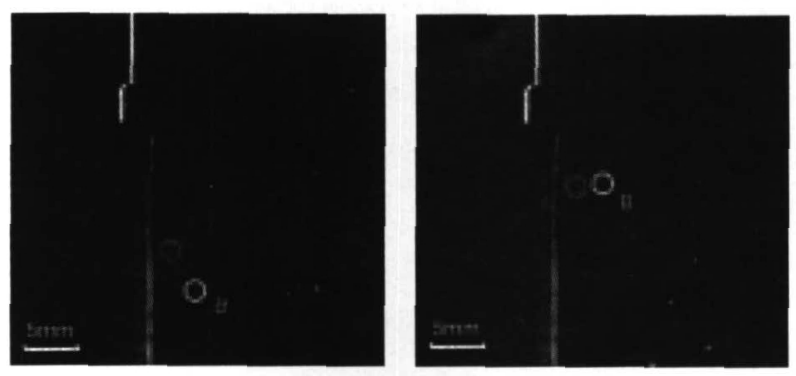

試験片上部
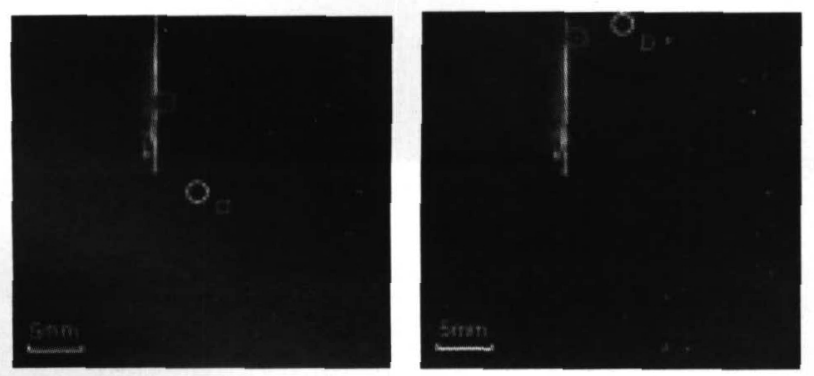

試験片下部

$\mathrm{t}=0 \mathrm{~s} \quad \mathrm{t}=0.2 \mathrm{~s}$

Fig.9 試験片近傍における流れの様子（液温 $20^{\circ} \mathrm{C}$ )

\section{4. 結言}

本研究では, 油焼入れ実験を行い, 焼入れ部品におけ る冷却の均一化を図るために冷却剂の鲤汼と油温の調節 を行った. そして, それらが焼入れ中に発生する蒸気膜 へ及ぼす影響をハイスピードカメラ, PIV 測定, 熱電対 を用いて観察を行い, それらより焼入れ過程における焼 入れ油の伝熱挙動と熱流れの可視化を行った. また, 本 実験装置における流れの定量化を行うために, 冷却槽内 の各部において流れの測定を行い, その挙動の検証を行 った.

\section{謝辞}

本研究には，(株) 日昌エンジニアリング 田中貢様より 多大なご協力をいただいた．ここに記して感謝の意を示 す.

\section{参考文献}

1 社団法人 可視化情報学会 JOURNAL OF THE VISUALIZATION SOCIETY OF JAPAN, Vol. 21 No. 80 pp. 2-33(2001)

2 社団法人 可視化情報学会 PIV 技術入門 （株）春 恒社, pp. 9-34 (2000) 